\title{
Urban and rural area differences in the interaction between oxidative process elements in human femoral bone
}

\author{
Mikołaj Dąbrowski ${ }^{1,2} \cdot$ Anetta Zioła-Frankowska ${ }^{3} \cdot$ Łukasz Kubaszewski $^{1,2} \cdot$ Piotr Rogala $^{1} \cdot$ Marcin Frankowski $^{4}$
}

Received: 30 May 2018 / Accepted: 24 August 2018 / Published online: 30 August 2018

(C) The Author(s) 2018

\begin{abstract}
Elements in the human body come from contaminated food, water, and air from the living area. Bones are a marker of long-term exposure to elements and show a relationship between them. The aim of the study was to analyze the correlation between the contents of $\mathrm{Zn}, \mathrm{Cu}, \mathrm{Fe}, \mathrm{Mo}, \mathrm{Cr}, \mathrm{Ni}, \mathrm{Ba}, \mathrm{Sr}$, and $\mathrm{Pb}$ in the proximal femoral head (cancellous bone) and femoral neck (cortical bone) in rural and urban populations. The study included 96 patients who were operated on for total hip replacement (THR), acquired in a surgical procedure with atomic absorption spectrometry, and the content of $\mathrm{Zn}, \mathrm{Cu}, \mathrm{Fe}, \mathrm{Mo}, \mathrm{Cr}, \mathrm{Ni}, \mathrm{Ba}, \mathrm{Sr}$, and $\mathrm{Pb}$ was evaluated. In rural areas, significant negative correlations were observed for $\mathrm{Mo} / \mathrm{Cr}, \mathrm{Mo} / \mathrm{Cu}$, and $\mathrm{Ni} / \mathrm{Fe}$, and positive correlations were observed for $\mathrm{Fe} / \mathrm{Zn}$ and $\mathrm{Pb} / \mathrm{Zn}$. In urban areas, a negative correlation was found for $\mathrm{Pb} / \mathrm{Mo} . \mathrm{Pb}$ and $\mathrm{Ni}$ increased with age only in villagers, and $\mathrm{Zn}$ and $\mathrm{Sr}$ decreased with age in urban citizens. Ba decreased with age in people from rural areas. The correlation showed variances mainly in molybdenum, nickel, and oxidative elements between rural and urban populations.
\end{abstract}

Keywords Rural $\cdot$ Urban $\cdot$ Trace elements $\cdot$ Environmental factors $\cdot$ Femoral bone

\section{Introduction}

The sources of elements in the human body are contaminated food, water, and air from the living area (Berglund et al. 2000). Air pollution is higher in cities compared to rural areas (Gonzalez-Reimers et al. 2014). The metal content of the soil

Responsible editor: Philippe Garrigues

Mikołaj Dąbrowski

md@twt.net.pl

Anetta Zioła-Frankowska

anettazf@amu.edu.pl

1 Department of Spondyloortopaedics and Biomechanics of the Spine, W. Dega University Hospital, Poznan University of Medical Sciences, 28 Czerwca 1956 135/147, 61-545 Poznan, Poland

2 Department of Orthopaedics and Traumatology, W. Dega University Hospital, Poznan University of Medical Sciences, 28 Czerwca 1956 135/147, 61-545 Poznan, Poland

3 Faculty of Chemistry, Department of Analytical Chemistry, Adam Mickiewicz University in Poznan, Umultowska 89b, 61-614 Poznan, Poland

4 Faculty of Chemistry, Department of Water and Soil Analysis, Adam Mickiewicz University in Poznan, Umultowska 89b, 61-614 Poznan, Poland depends on the particular type of industry in the area: $\mathrm{Pb}, \mathrm{Zn}$, $\mathrm{Ni}, \mathrm{Cu}, \mathrm{Fe}$, and $\mathrm{As}$ in smelter and metal industries; $\mathrm{Mn}$ and $\mathrm{Cd}$ in the textile industry; and $\mathrm{Cr}$ in the leather industry (Kabir et al. 2012).

Previous studies of the content of metals in the human bone have shown the influence of such factors as gender, smoking, physical activity, alcohol consumption, and air pollution (Lanocha-Arendarczyk et al. 2015, Zioła-Frankowska et al. 2015a, b, 2017). The study of Zioła-Frankowska et al. showed higher $\mathrm{Pb}, \mathrm{Cr}$, and $\mathrm{Ni}$ content in smokers, higher concentrations of $\mathrm{Pb}, \mathrm{Ni}$, and $\mathrm{Cu}$ in people who consume alcohol, and also higher $\mathrm{Pb}, \mathrm{Cu}, \mathrm{Zn}$, and Ni concentrations in men (ZiołaFrankowska et al. 2015b). In addition, Hg content of the femoral neck with the increase of body mass index (BMI) has been demonstrated (Zioła-Frankowska et al. 2017). Another study showed that content of $\mathrm{Al}$ in the femoral head and neck was strictly dependent on type of medicines taken, contact with chemicals at work, differences in body anatomy, and sex (Zioła-Frankowska et al. 2015a).

It should be underlined that the slow metabolism of bones causes them to be markers for long-term exposure to elements, including heavy metals (Zaichick et al. 2011). Cancellous bone has faster turnover than cortical bone and is associated with place of residence (Boonen et al. 1997). The content and correlations between the rings depend on the location of bone 
sampling along the bone area. It is suggested to select bone tissue as a tissue for monitoring inorganic contaminants and standardize the method of sampling in order to allow comparison of results between studies (Lazarus et al. 2018).

Differences in the femoral bone correlation of metals between persons living in urban and rural areas can show the degree of environmental pollution and the influence of metals on the human musculoskeletal system (Budis et al. 2014). Toxicity of environmental pollutant mechanism is associated with inflammation, oxidative stress, metabolic disorders, and epigenetic mechanism. The pollutions disrupt the homeostatic status and lead to adverse health effects. This perturbation of homeostatic balance can be most noticeable in older adults (Fougère et al. 2015). The production of free radicals is a process in which metals, such as $\mathrm{Fe}, \mathrm{Cu}, \mathrm{Cr}$, and $\mathrm{Co}$, are involved, transferring electrons between metals and substrates (Matés et al. 2008). The physiological oxidative state in the cell can be interrupted by the uncontrolled formation of free radicals leading to DNA modification and lipid peroxidation (Valko et al. 2007). The experimental study showed that the accumulation of iron leads to the production of reactive oxygen species (ROS) which stimulates the differentiation of osteoclasts and iron-induced osteopenia in mouse model (Wang et al. 2018). The literature reports the toxicity of $\mathrm{Cr}^{3+}, \mathrm{Fe}^{3+}$, $\mathrm{Ni}^{2+}$, and $\mathrm{Mo}^{3+}$ and their impact on cell viability in vitro (Terpilowska and Siwicki 2018). There are a few pieces of information about the correlation between these elements and their influence on human systems. Moreover, the studies of these trace elements are important because they are used alone and in combination in diet supplements and they are component of biomaterials implanted in medicine.

Given that previous research mainly concerned quantitative analysis, the aim of this study was to identify the differences between urban and rural areas in the concentrations of $\mathrm{Zn}, \mathrm{Cu}$, $\mathrm{Fe}, \mathrm{Mo}, \mathrm{Cr}, \mathrm{Ni}, \mathrm{Ba}, \mathrm{Sr}$, and $\mathrm{Pb}$ in the proximal femoral head (FH) (cancellous bone) and femoral neck (FN) (cortical bone) of the hip joint affected by osteoarthritis.

\section{Materials and methods}

The study material included parts of the femoral bone obtained during surgical operation on for total hip replacement (THR). Biological samples were taken from patients living in Wielkopolska Region of Poland. Biological samples were collected from 96 patients, including 57 women, of whom 18 were residents of villages and 39 of cities, and 39 men, of whom six were residents of villages and 33 of cities. The mean age of the women study population was $64.5 \pm 14.2$ years (range $=25-87$ years) and for men it was $63.2 \pm 10.2$ years (range 42-91 years). Inhabitants of cities were significantly older than inhabitants of rural areas $(65.5 \pm 12.6$ vs $57.8 \pm$ $13.3, p<0.05)$. A history of disease did not affect the outcome of the study. There is no major industry concentration in this region. Detailed and accurate information about characteristics of patients and femoral bone samples are presented in the studies by Zioła-Frankowska et al. (2015a, b).

The study was approved by the Bioethical Committee (permit no. 172/4) of the University of Medical Sciences in Poznan (Poland). All patients included in the study provided written informed consent prior to participation. The femoral bone was collected intraoperatively from the patients during hip replacement procedure. The samples were taken from two anatomic regions of each type of resected fragment in situ with an orthopedic oscillating saw: the FH and FN. The bone samples were taken without articular capsule and without articular cartilage. After excision, the biological samples were frozen at $-20{ }^{\circ} \mathrm{C}$ in polyethylene containers.

The frozen bone samples were freeze-dried using a lyophilizer (Lyovac GT2e; Steris, Germany) for $24 \mathrm{~h}$. Then, a known mass $0.5 \mathrm{~g}$ of the sample was weighed and placed in a Teflon bomb Mars 5 Xpress microwave oven (CEM, USA). Next, the 10-mL volume of suprapure nitric acid (V) (Merck, Germany) was added to each sample and allowed to stand for $8 \mathrm{~h}$ to slow mineralization. After that, the samples were mineralized in a microwave oven using a modified EPA method 3051 (Frankowski et al. 2013). The post-mineralization extract was placed into flasks and filled with $50-\mathrm{mL}$ demineralized water. It should be underlined that extracts of bone samples after digestion were clear and colorless or slightly yellow, with no visible sediment and fat residues.

The concentrations of $\mathrm{Mo}, \mathrm{Cr}, \mathrm{Zn}, \mathrm{Pb}, \mathrm{Cu}, \mathrm{Ni}, \mathrm{Fe}, \mathrm{Ba}$, and $\mathrm{Sr}$ in mineralized samples were determined using inductively coupled plasma atomic emission spectrometry (ICP-AES) Jobin Yvon, 170Ultrace (Jobin Yvon, France) with laterally viewed plasma. The samples were nebulized using a concentric Meinhard nebulizer. The analytical conditions of ICPAES were used: RF power $1200 \mathrm{~W}$, plasma gas flow $12 \mathrm{~L} /$ min, auxiliary gas flow $0.4 \mathrm{~L} / \mathrm{min}$, nebulizer (carrier) gas $0.6 \mathrm{~L} / \mathrm{min}$, sample flow rate $1.0 \mathrm{~mL} / \mathrm{min}$, cleaning time $30 \mathrm{~s}$, replicates -3 , and emission lines of $\mathrm{Zn}: \lambda=213.8 \mathrm{~nm}, \mathrm{Cu}: \lambda=$ $224.7 \mathrm{~nm}$, Fe: $\lambda=259.9 \mathrm{~nm}$, Mo: $\lambda=204.6 \mathrm{~nm}, \mathrm{Cr}: \lambda=$ $205.5 \mathrm{~nm}, \mathrm{Ni}: \lambda=231.6 \mathrm{~nm}, \mathrm{Ba}: \lambda=455.4 \mathrm{~nm}, \operatorname{Sr}: \lambda=$ $407.8 \mathrm{~nm}$, and $\mathrm{Pb}: \lambda=220.3 \mathrm{~nm}$. During analysis, the calibration curve method was applied. The standard deviation did not exceed 5\% for the results of average of the content determined for all analytical lines applied for the each element. The accuracy of the performed procedure was controlled by analysis of the Standard Reference Material 1400 Bone Ash (National Institute of Standard and Technology (NIST)) using ICPAES analytical technique. The recoveries for analyzed elements varied from 94.6 to $109 \%$.

The statistical analysis was performed with Statistica PL v.12.0 (StatSoft, Tulsa, USA) software. Moreover, the Spearman's rank correlation between selected elements occurring in different parts of the hip joint (femoral neck and 
femoral head bone) and epidemiological data, including age, sex, and place of residence (urban and rural area), was performed. The $p$ values $<0.05$ were considered statistically significant. The chemometric analysis to evaluate variables from the independent assumption showing the mutual relations between the analyzed factors was performed by applied principal component analysis (PCA).

\section{Results and discussion}

\section{Molybdenum and nickel}

The analysis of the correlation findings in terms of place of residence showed variances mainly in molybdenum and nickel.

In rural areas, the correlation of Mo with $\mathrm{Cr}$ content was significant negatively correlated (Tables 1 and 2). In further gender group analysis, a similar correlation was found both in females in the FH (Table 3) and in men in the FN (Table 6).

In the group analysis of the place of residence, a statistically significant negative correlation of $\mathrm{Mo} / \mathrm{Cu}$ was found in the group of rural people in the FH (Table 2). In further gender group analysis, a correlation was found mainly in women in rural areas (Table 3). The same correlation in the $\mathrm{FN}$ was more negative for women (cities $=-0.32$, villages $=-0.37$ ) than men $($ cities $=0.07$, villages $=-0.28)($ Tables 5 and 6). A significantly positive correlation of $\mathrm{Mo} / \mathrm{Zn}$ was found in the $\mathrm{FH}$ of men in urban areas (Table 4). In other groups' interaction, $\mathrm{Mo} /$ $\mathrm{Zn}$ was negative, but the values did not exceed the level -0.27 .

There was also a negative correlation between the content of $\mathrm{Mo} / \mathrm{Pb}$ in the $\mathrm{FN}$ in the urban population (Table 1). In further gender analysis, the correlation in the city was higher in men than in women $(-0.44$ vs -0.28$)$. This difference according to sex was also noticeable in men from rural areas although it was not statistically significant (Table 6).
The content of Mo in the analyzed femur bone decreased with age mainly in rural areas (Tables 1 and 2). Also in villages, in females' femoral head, the correlation coefficient of Mo with age was statistically significant opposite to the men (Table 3).

There were no significant interactions, and their differences depended on the sex and place of residence for $\mathrm{Mo} / \mathrm{Fe}$ (range $=-$ 0.27 to 0.26 ), $\mathrm{Mo} / \mathrm{Ni}$ (range $=-0.29$ to 0.17 ), $\mathrm{Mo} / \mathrm{Sr}$ (range $=-$ 0.18 to 0.21 ), and $\mathrm{Mo} / \mathrm{Ba}$ (range $=-0.3$ to 0.33 ).

The values of the correlation coefficients of $\mathrm{Ni} / \mathrm{Cr}$ in the $\mathrm{FN}$ were positive and similar in urban and rural populations, although they were statistically significant only in the first group (Table 1). In addition, further gender analysis showed significantly higher values for women both in urban and rural areas (Table 5).

Increased $\mathrm{Ni}$ content in the femur with age was demonstrated in rural areas (Tables 1 and 2). Especially in the group of men living in rural areas, the correlation coefficient was very high $(\mathrm{FN}=0.88, \mathrm{FH}=0.94)$.

Also, we observed that the correlation of Ni/Ba was negative only in rural areas in men (Tables 4 and 6). A negative tendency of $\mathrm{Ni} / \mathrm{Zn}$ correlation was noted, although low and statistically insignificant. Correlation values were similar only in men in the $\mathrm{FH}$ (cities $=-0.42$, villages $=-0.46$ ).

The correlation of $\mathrm{Ni} / \mathrm{Fe}$ content of the $\mathrm{FN}$ was significantly positive only in rural areas (0.47) and was independent of sex (Tables 5 and 6). Correlation was not found in the FH, although the value of male dependency $(-0.76)$ was notable. Even though no statistically significant correlation was found, the results may not be fully reliable due to the small number $(n=6)$.

\section{Oxidative process elements}

In our study, we also checked the possible correlation between metals responsible for oxidative process. The $\mathrm{Cr} / \mathrm{Fe}$
Table 1 Spearman correlation coefficients for metals found in femoral neck in according place of residence

\begin{tabular}{lllllllllll}
\hline Neck & $\mathrm{Mo}$ & $\mathrm{Cr}$ & $\mathrm{Zn}$ & $\mathrm{Cu}$ & $\mathrm{Ni}$ & $\mathrm{Fe}$ & $\mathrm{Sr}$ & $\mathrm{Ba}$ & $\mathrm{Pb}$ & Age \\
\hline & & & & & & & & & & Cities \\
$\mathrm{Mo}$ & $\mathrm{x}$ & 0.19 & -0.13 & -0.15 & -0.02 & 0.01 & -0.01 & -0.02 & $-0.35^{*}$ & -0.01 \\
$\mathrm{Cr}$ & -0.33 & $\mathrm{x}$ & -0.04 & $0.25^{*}$ & $0.31^{*}$ & $0.38^{*}$ & -0.07 & -0.09 & -0.15 & 0.02 \\
$\mathrm{Zn}$ & -0.18 & -0.10 & $\mathrm{x}$ & -0.03 & -0.06 & -0.11 & $0.33^{*}$ & 0.16 & 0.17 & $-0.25^{*}$ \\
$\mathrm{Cu}$ & -0.25 & 0.39 & -0.32 & $\mathrm{x}$ & $0.48^{*}$ & $0.27^{*}$ & -0.10 & -0.23 & -0.12 & 0.15 \\
$\mathrm{Ni}$ & -0.08 & 0.35 & -0.38 & $0.86^{*}$ & $\mathrm{x}$ & 0.03 & 0.09 & -0.19 & -0.03 & -0.09 \\
$\mathrm{Fe}$ & -0.18 & 0.36 & -0.36 & $0.54^{*}$ & $0.47^{*}$ & $\mathrm{x}$ & -0.19 & -0.17 & -0.31 & 0.00 \\
$\mathrm{Sr}$ & 0.05 & -0.08 & $0.56^{*}$ & -0.35 & -0.17 & -0.24 & $\mathrm{x}$ & $0.27^{*}$ & 0.15 & $-0.32^{*}$ \\
$\mathrm{Ba}$ & 0.17 & -0.04 & 0.36 & -0.07 & -0.09 & -0.05 & $0.46^{*}$ & $\mathrm{x}$ & 0.15 & -0.14 \\
$\mathrm{~Pb}$ & -0.19 & -0.23 & $0.46^{*}$ & 0.22 & 0.03 & -0.06 & 0.08 & -0.04 & $\mathrm{x}$ & 0.02 \\
$\mathrm{Age}$ & -0.21 & -0.31 & 0.03 & 0.33 & 0.33 & -0.19 & -0.27 & -0.32 & $0.46^{*}$ & $\mathrm{x}$ \\
& Villages & & & & & & & & & \\
\hline
\end{tabular}

${ }^{\text {a }}$ Statistically significant correlation 
correlation was positive in each group and significant in the FN and FH of women from cities (Tables 3 and 5). In men, the Spearman coefficient of $\mathrm{Cr} / \mathrm{Fe}$ was lower, at a maximum of 0.33 . In villages, $\mathrm{Cr}$ decreased with age in the $\mathrm{FN}$ of women and increased with age in the $\mathrm{FH}$ of men. The $\mathrm{Cr} / \mathrm{Zn}$ correlation was negative only in the FN of men (Table 6).

Interesting observations arise from the analysis of $\mathrm{Cu}$ content, namely, its content in the femur increased with age (although not statistically significant) only in the rural population (villages: $\mathrm{FH}=0.32, \mathrm{FN}=0.33$ vs cities: $\mathrm{FH}=0, \mathrm{FN}=0.15$ ). The Spearman coefficient of $\mathrm{Cu} /$ age was significantly higher for men living in rural areas (Tables 4 and 6). The correlation of $\mathrm{Cu} / \mathrm{Cr}$ was highly positive independent of the place residence, and slightly higher values were found in men, with the lowest for women living in cities $(\mathrm{FN}=0.18)$. Also, the $\mathrm{Cu} / \mathrm{Fe}$ interaction was significant only in the $\mathrm{FN}$, and the value was higher in rural areas both in women and in men (Table 1).

We also found a high correlation of $\mathrm{Cu} / \mathrm{Ni}$ in the $\mathrm{FN}$ (villages $=0.86$ vs cities $=0.48$ ). However, the correlation in the $\mathrm{FN}$ was higher in the rural population, while in the $\mathrm{FH}$, the values were similar but statistically significant in the case only of urban areas (Table 2).

$\mathrm{The} \mathrm{Fe} / \mathrm{Zn}$ content in rural areas was positive in the $\mathrm{FH}$ and negative in the FN (Tables 1 and 2). A negative correlation of $\mathrm{Zn} / \mathrm{Cu}$ was found in the $\mathrm{FN}$ of men living in villages (Table 6) and cities in both types of bone (Tables 4 and 6). In women, those elements did not interact significantly. It should be underlined that we observed a tendency of $\mathrm{Zn}$ to decrease with age in femoral head; the most visible was in men from rural areas $(-0.37)$ and the least in men from cities $(0.02)$.

In the case of $\mathrm{Fe}$, in rural areas, we found a negative correlation of metal with age in the FN of women and the FH of men ( -0.26 and -0.66 , respectively). Moreover, the FH of women demonstrated increased Fe content with age (rural $=0.37$, urban $=0.48$ ), and no correlation was found in other groups.

\section{Barium and strontium}

Men in urban areas showed a significant decrease in $\mathrm{Sr}$ content in the FN with age, which was most visible in the FN in men from urban areas (Table 6). $\mathrm{Sr} / \mathrm{Fe}$ correlation was negative regardless of the place of residence of men in the FN (Table 6). In other groups, the $\mathrm{Sr} / \mathrm{Fe}$ correlation was insignificant (maximum 0.2 ). The $\mathrm{Ni} / \mathrm{Sr}$ correlation was not determined by sex or area, and Spearman coefficient values were low (range $=-0.2$ to 0.29 ). For interactions of $\mathrm{Sr} / \mathrm{Cr}$ and $\mathrm{Sr} /$ $\mathrm{Cu}$, we did not obtain significant value in the $\mathrm{FN}$ of men from rural areas, and in other subgroups, it did not show absolute values above 0.2 . $\mathrm{Zn} / \mathrm{Sr}$ correlation was significantly positive, although the lowest values were found in the FN of women (rural $=0.27$, urban $=0.33$ ) and the highest in the FH in cities $($ men $=0.61$, women $=0.58)$.

We showed a positive correlation of $\mathrm{Ba} / \mathrm{Sr}$ regardless of the place of residence, but much higher correlation coefficients were found in women (Tables 3 and 4). Interesting results were obtained in relation to $\mathrm{Ba}$ in the femoral bone of males from villages. Negative correlations with oxidative metals were found, including statistically significant ones, and the highest coefficients were obtained for $\mathrm{Ba} / \mathrm{Cr}$ and $\mathrm{Ba} / \mathrm{Cu}$ (Tables 4 and 6). For urban areas, the correlation coefficients of $\mathrm{Ba} / \mathrm{Mo}, \mathrm{Cr}, \mathrm{Zn}$, and $\mathrm{Cu}$ did not exceed 0.3 , except for the correlation $\mathrm{Ba} / \mathrm{Fe}$, which was not determined by sex or area, and Spearman coefficient values were low (range $=-0.24$ to 0.14 ). We found a $\mathrm{Ba} / \mathrm{Zn}$ correlation in women from cities (Table 3 ). It is worth mentioning that the $\mathrm{Ba}$ content in the bones decreased with age in both men and women.

In rural areas, the absolute values of correlation coefficients were higher than those of urban residents (although statistical significance was not demonstrated) and ranged from -0.54 to -0.31 in rural areas and -0.15 to 0.17 in urban areas.
Table 2 Spearman correlation coefficients for metals found in femoral head in according place of residence

\begin{tabular}{lllllllllll}
\hline Head & $\mathrm{Mo}$ & $\mathrm{Cr}$ & $\mathrm{Zn}$ & $\mathrm{Cu}$ & $\mathrm{Ni}$ & $\mathrm{Fe}$ & $\mathrm{Sr}$ & $\mathrm{Ba}$ & $\mathrm{Pb}$ & Age \\
\hline & & & & & & & & & & Cities \\
$\mathrm{Mo}$ & $\mathrm{x}$ & 0.05 & 0.15 & -0.14 & -0.07 & 0.15 & 0.01 & 0.01 & 0.02 & 0.14 \\
$\mathrm{Cr}$ & $-0.49^{\mathrm{a}}$ & $\mathrm{x}$ & -0.08 & $0.38^{\mathrm{a}}$ & 0.11 & $0.38^{\mathrm{a}}$ & -0.09 & 0.06 & -0.21 & 0.13 \\
$\mathrm{Zn}$ & -0.11 & 0.08 & $\mathrm{x}$ & -0.12 & -0.14 & 0.01 & $0.59^{\mathrm{a}}$ & $0.43^{\mathrm{a}}$ & 0.09 & -0.16 \\
$\mathrm{Cu}$ & $-0.53^{\mathrm{a}}$ & $0.62^{\mathrm{a}}$ & -0.09 & $\mathrm{x}$ & $0.45^{\mathrm{a}}$ & 0.22 & -0.06 & -0.13 & -0.06 & 0.00 \\
$\mathrm{Ni}$ & -0.23 & 0.32 & -0.18 & 0.36 & $\mathrm{x}$ & -0.15 & -0.03 & 0.08 & -0.14 & -0.15 \\
$\mathrm{Fe}$ & -0.21 & 0.26 & $0.41^{\mathrm{a}}$ & -0.02 & -0.14 & $\mathrm{x}$ & -0.11 & 0.02 & 0.26 & 0.20 \\
$\mathrm{Sr}$ & 0.13 & -0.09 & 0.37 & -0.21 & -0.15 & 0.17 & $\mathrm{x}$ & $0.40^{\mathrm{a}}$ & 0.06 & -0.19 \\
$\mathrm{Ba}$ & -0.03 & 0.04 & 0.33 & -0.26 & -0.19 & -0.15 & $0.43^{\mathrm{a}}$ & $\mathrm{x}$ & 0.12 & -0.02 \\
$\mathrm{~Pb}$ & 0.03 & 0.03 & 0.01 & -0.02 & 0.01 & -0.02 & -0.09 & 0.02 & $\mathrm{x}$ & 0.07 \\
$\mathrm{Age}$ & -0.40 & 0.09 & -0.20 & 0.32 & $0.46^{\mathrm{a}}$ & 0.15 & -0.19 & $-0.41^{\mathrm{a}}$ & 0.03 & $\mathrm{x}$ \\
& Villages & & & & & & & & & \\
\hline
\end{tabular}

${ }^{\text {a }}$ Statistically significant correlation 
Table 3 Spearman correlation coefficients for metals found in femoral head in women in according place of residence

\begin{tabular}{lllllllllll}
\hline Head & Mo & $\mathrm{Cr}$ & $\mathrm{Zn}$ & $\mathrm{Cu}$ & $\mathrm{Ni}$ & $\mathrm{Fe}$ & $\mathrm{Sr}$ & $\mathrm{Ba}$ & $\mathrm{Pb}$ & Age \\
\hline Women & & & & & & & & & & Cities \\
$\mathrm{Mo}$ & $\mathrm{x}$ & 0.02 & 0.04 & -0.17 & 0.17 & 0.11 & -0.13 & -0.01 & 0.21 & 0.09 \\
$\mathrm{Cr}$ & $-0.49^{\mathrm{a}}$ & $\mathrm{x}$ & -0.07 & $0.35^{\mathrm{a}}$ & 0.17 & $0.39^{\mathrm{a}}$ & -0.10 & 0.08 & -0.25 & 0.15 \\
$\mathrm{Zn}$ & 0.17 & -0.11 & $\mathrm{x}$ & -0.13 & 0.07 & -0.04 & $0.58^{\mathrm{a}}$ & $0.45^{\mathrm{a}}$ & -0.09 & -0.18 \\
$\mathrm{Cu}$ & $-0.69^{\mathrm{a}}$ & $0.58^{\mathrm{a}}$ & -0.11 & $\mathrm{x}$ & $0.32^{\mathrm{a}}$ & 0.04 & -0.09 & -0.23 & -0.19 & 0.12 \\
$\mathrm{Ni}$ & -0.19 & 0.33 & -0.37 & 0.24 & $\mathrm{x}$ & -0.27 & 0.15 & 0.13 & 0.02 & -0.14 \\
$\mathrm{Fe}$ & -0.28 & 0.30 & 0.34 & 0.13 & 0.18 & $\mathrm{x}$ & -0.07 & 0.00 & -0.07 & $0.48^{\mathrm{a}}$ \\
$\mathrm{Sr}$ & 0.16 & -0.09 & $0.54^{\mathrm{a}}$ & -0.24 & -0.20 & 0.09 & $\mathrm{x}$ & $0.46^{\mathrm{a}}$ & -0.22 & -0.25 \\
$\mathrm{Ba}$ & 0.08 & 0.19 & 0.32 & -0.03 & -0.25 & -0.24 & $0.63^{\mathrm{a}}$ & $\mathrm{x}$ & -0.04 & -0.10 \\
$\mathrm{~Pb}$ & 0.01 & 0.07 & 0.05 & 0.07 & 0.00 & 0.16 & 0.04 & 0.06 & $\mathrm{x}$ & 0.05 \\
$\mathrm{Age}$ & $-0.51^{\mathrm{a}}$ & 0.07 & -0.29 & 0.20 & 0.29 & 0.37 & -0.40 & -0.45 & 0.16 & $\mathrm{x}$ \\
& Villages & & & & & & & & & \\
\hline
\end{tabular}

${ }^{\text {a }}$ Statistically significant correlation

\section{Lead}

A significantly positive correlation between age and the concentration of $\mathrm{Pb}$ in the $\mathrm{FN}$ was found in the rural population (Table 1). We found other interactions in men in the rural group in both types of sample: $\mathrm{Pb} / \mathrm{Zn}, \mathrm{Pb} / \mathrm{Cr} \mathrm{Pb} / \mathrm{Cu} \mathrm{Pb} / \mathrm{Ni}$, $\mathrm{Pb} / \mathrm{Fe}, \mathrm{Pb} / \mathrm{Ba}$, and $\mathrm{Pb} / \mathrm{Sr}$ (Tables 4 and 6).

\section{Chemometric analysis}

PCA showed a difference between urban and rural populations for the first factor for $\mathrm{Mo}, \mathrm{Ni}, \mathrm{Cu}, \mathrm{Cr}, \mathrm{Zn}$, and $\mathrm{Ba}$ (Figs. 1 and 2). The second factor describes the difference between urban and rural of $\mathrm{Zn}$ only in the $\mathrm{FH}$ and $\mathrm{Sr}$ (Figs. 1 and 2).

In the PCA, the elements can be divided into two groups: $\mathrm{Ni}$ and $\mathrm{Cu}$ in the $\mathrm{FN}$ and additionally $\mathrm{Cr}$ in the $\mathrm{FH}$, as a first factor, to take the opposite values for villages and cities. The second group includes $\mathrm{Sr}, \mathrm{Ba}$, and $\mathrm{Zn}$ as a second factor to take opposite values for villages and cities, which is particularly visible in the FH (Figs. 1 and 2). Gender-based analysis confirms the division into the above groups; in particular, in the $\mathrm{FH}, \mathrm{Pb}$ variation can be observed in relation to the second factor between cities and villages (Figs. 3 and 4).

Previous studies have described the existence of heavy metals in several regions of Poland. Jurkiewicz et al. evaluated the same content of $\mathrm{Ca}, \mathrm{P}, \mathrm{Mg}, \mathrm{P}, \mathrm{Fe}, \mathrm{Zn}$, $\mathrm{Cu}, \mathrm{Pb}, \mathrm{Cd}, \mathrm{As}$, and $\mathrm{Ag}$ in the FHs of inhabitants of southern Poland (Silesia, Cracow) and middle Poland (Lodz) (Jurkiewicz et al. 2004). Specimens from different regions differed in $\mathrm{Pb}$ and $\mathrm{Cd}$ content, illustrating the differences in environmental pollution exposure. Budis et al. found no statistically significant residence-related differences in the concentrations of $\mathrm{Sr}, \mathrm{Mn}$, or Fe (Budis et al. 2014).
Table 4 Spearman correlation coefficients for metals found in femoral head in men in according place of residence

\begin{tabular}{llllllllll}
\hline $\mathrm{Head}$ & $\mathrm{Cr}$ & $\mathrm{Zn}$ & $\mathrm{Cu}$ & $\mathrm{Ni}$ & $\mathrm{Fe}$ & $\mathrm{Sr}$ & $\mathrm{Ba}$ & $\mathrm{Pb}$ & Age \\
\hline $\mathrm{Men}$ & & & & & & & & & Cities \\
$\mathrm{Mo}$ & 0.11 & $0.47^{\mathrm{a}}$ & -0.05 & -0.27 & 0.26 & 0.21 & 0.07 & -0.10 & 0.16 \\
$\mathrm{Cr}$ & $\mathrm{x}$ & -0.12 & $0.49^{\mathrm{a}}$ & 0.09 & 0.33 & -0.03 & 0.03 & -0.19 & 0.06 \\
$\mathrm{Zn}$ & 0.14 & $\mathrm{x}$ & -0.31 & $-0.42^{\mathrm{a}}$ & 0.11 & $0.61^{\mathrm{a}}$ & 0.29 & 0.16 & 0.02 \\
$\mathrm{Cu}$ & $0.94^{\mathrm{a}}$ & 0.03 & $\mathrm{x}$ & $0.47^{\mathrm{a}}$ & 0.30 & -0.03 & -0.06 & -0.12 & -0.02 \\
$\mathrm{Ni}$ & 0.58 & -0.46 & 0.74 & $\mathrm{X}$ & -0.10 & -0.18 & 0.06 & -0.08 & -0.10 \\
$\mathrm{Fe}$ & -0.09 & 0.54 & -0.39 & -0.76 & $\mathrm{x}$ & -0.10 & 0.04 & 0.05 & -0.02 \\
$\mathrm{Sr}$ & -0.14 & 0.37 & -0.21 & 0.03 & 0.20 & $\mathrm{x}$ & 0.32 & -0.04 & -0.03 \\
$\mathrm{Ba}$ & $-0.94^{\mathrm{a}}$ & -0.31 & $-0.94^{\mathrm{a}}$ & -0.58 & 0.14 & 0.03 & $\mathrm{x}$ & 0.04 & 0.17 \\
$\mathrm{~Pb}$ & -0.13 & -0.13 & -0.42 & -0.42 & 0.65 & 0.13 & 0.39 & $\mathrm{x}$ & 0.25 \\
$\mathrm{Age}$ & 0.43 & -0.37 & 0.58 & $0.94^{\mathrm{a}}$ & -0.66 & 0.31 & -0.49 & -0.39 & $\mathrm{x}$ \\
& Villages & & & & & & & & \\
\hline
\end{tabular}

${ }^{\text {a }}$ Statistically significant correlation 
Table 5 Spearman correlation coefficients for metals found in femoral neck in women in according place of residence

\begin{tabular}{lllllllllll}
\hline Neck & $\mathrm{Mo}$ & $\mathrm{Cr}$ & $\mathrm{Zn}$ & $\mathrm{Cu}$ & $\mathrm{Ni}$ & $\mathrm{Fe}$ & $\mathrm{Sr}$ & $\mathrm{Ba}$ & $\mathrm{Pb}$ & Age \\
\hline Women & & & & & & & & & & Cities \\
$\mathrm{Mo}$ & $\mathrm{x}$ & 0.18 & -0.03 & $-0.32^{\mathrm{a}}$ & 0.10 & 0.05 & 0.16 & 0.18 & -0.28 & -0.21 \\
$\mathrm{Cr}$ & -0.25 & $\mathrm{x}$ & 0.16 & 0.18 & $0.38^{\mathrm{a}}$ & $0.52^{\mathrm{a}}$ & 0.00 & -0.04 & -0.14 & -0.07 \\
$\mathrm{Zn}$ & -0.18 & -0.01 & $\mathrm{x}$ & 0.21 & 0.01 & -0.02 & $0.33^{\mathrm{a}}$ & 0.13 & 0.01 & -0.27 \\
$\mathrm{Cu}$ & -0.37 & $0.49^{\mathrm{a}}$ & 0.06 & $\mathrm{x}$ & $0.43^{\mathrm{a}}$ & $0.40^{\mathrm{a}}$ & -0.06 & -0.31 & 0.24 & 0.07 \\
$\mathrm{Ni}$ & -0.06 & $0.52^{\mathrm{a}}$ & -0.22 & $0.83^{\mathrm{a}}$ & $\mathrm{x}$ & 0.23 & -0.15 & -0.25 & 0.06 & -0.10 \\
$\mathrm{Fe}$ & -0.29 & 0.36 & -0.25 & $0.62^{\mathrm{a}}$ & $0.55^{\mathrm{a}}$ & $\mathrm{x}$ & 0.07 & -0.20 & -0.08 & 0.04 \\
$\mathrm{Sr}$ & 0.24 & 0.20 & 0.27 & 0.06 & 0.11 & -0.16 & $\mathrm{x}$ & $0.39^{\mathrm{a}}$ & -0.19 & -0.26 \\
$\mathrm{Ba}$ & 0.06 & 0.31 & 0.39 & 0.17 & 0.00 & -0.04 & 0.45 & $\mathrm{x}$ & -0.22 & -0.15 \\
$\mathrm{~Pb}$ & -0.18 & -0.10 & 0.34 & 0.01 & -0.01 & -0.15 & -0.19 & 0.06 & $\mathrm{x}$ & 0.20 \\
$\mathrm{Age}$ & -0.22 & -0.43 & 0.23 & 0.14 & 0.10 & -0.26 & -0.32 & -0.31 & $0.61^{\mathrm{a}}$ & $\mathrm{x}$ \\
& Villages & & & & & & & & & \\
\hline
\end{tabular}

${ }^{\text {a }}$ Statistically significant correlation

\section{Chromium, molybdenum, zinc, iron, and diabetes}

Interestingly, the correlation noted in regard to $\mathrm{Mo} / \mathrm{Cr}$ is negative in persons living in rural areas. In this study, five patients (two women and three men) were diagnosed with diabetes, and most (four patients) lived in the city. Similar negative correlations were observed in the hair study population living in an urban population group in a large industrial center of southwest Poland (Chojnacka et al. 2005). Molybdenum plays a role in blood glucose level. Sodium molybdate prevented hyperinsulinemia in rats (Güner et al. 2001). Ajibola et al. showed that a significant increase of plasma glucose was significantly correlated with decreases of $\mathrm{Cr}$ and $\mathrm{Zn}$, with significant increases of molybdenum compared to the control (Ajibola et al. 2014). This can confirm the fact that in inhabitants of Lower Silesia (Poland), diabetes and impaired fasting glucose were more common in men and the rural population (Zatońska et al. 2017).
The chromium, especially a water-soluble complex $\mathrm{Cr}$, and niacin are co-factors for insulin and glucose tolerance. The content of $\mathrm{Zn}$ and $\mathrm{Cr}$ decreased in blood and scalp hair of diabetic patients of both genders (Kazi et al. 2008). Zn is utilized in the beta cells of the pancreas to release of insulin. Supplementation of $\mathrm{Zn}$ can lead to improvement in diabetics (Maanvizhi et al. 2014). Urinary $\mathrm{Zn}$ is associated with diabetes risk (Feng et al. 2015). In metabolic syndrome, $\mathrm{Zn}$ is increased in erythrocytes and decreased in urine (Freitas et al. 2017). Mo could reduce the concentration of $\mathrm{Zn}$ in both the liver and muscle (Van Ryssen 1994). In this study, the antagonism of $\mathrm{Mo} / \mathrm{Cu}$ was demonstrated. In another study, antagonistic interaction of $\mathrm{Mo} / \mathrm{Cu}$ was associated with progress of diabetes complications (Flores et al. 2011). There was no difference in $\mathrm{Zn} / \mathrm{Fe}$ correlation in diabetics (Badran et al. 2016). In another study, it was showed that increased levels of $\mathrm{Cu}, \mathrm{Fe}$, and $\mathrm{Cu} / \mathrm{Zn}$ ratio and decreased levels of $\mathrm{Zn}$ correlated with the increased value of $\mathrm{HbA1c}$ in diabetics (Atari-Hajipirloo et al. 2016).
Table 6 Spearman correlation coefficients for metals found in femoral neck in men in according place of residence

\begin{tabular}{lllllllllll}
\hline Neck & $\mathrm{Mo}$ & $\mathrm{Cr}$ & $\mathrm{Zn}$ & $\mathrm{Cu}$ & $\mathrm{Ni}$ & $\mathrm{Fe}$ & $\mathrm{Sr}$ & $\mathrm{Ba}$ & $\mathrm{Pb}$ & Age \\
\hline $\mathrm{Men}$ & & & & & & & & & & Cities \\
$\mathrm{Mo}$ & $\mathrm{x}$ & 0.14 & -0.14 & 0.07 & -0.11 & -0.06 & -0.18 & -0.30 & $-0.44^{\mathrm{a}}$ & 0.22 \\
$\mathrm{Cr}$ & $-0.48^{\mathrm{a}}$ & $\mathrm{x}$ & -0.30 & $0.37^{\mathrm{a}}$ & 0.26 & 0.17 & -0.13 & -0.20 & -0.19 & 0.09 \\
$\mathrm{Zn}$ & -0.27 & -0.33 & $\mathrm{x}$ & -0.27 & -0.14 & -0.26 & $0.35^{\mathrm{a}}$ & 0.16 & 0.30 & -0.19 \\
$\mathrm{Cu}$ & -0.28 & 0.34 & -0.58 & $\mathrm{x}$ & $0.51^{\mathrm{a}}$ & 0.18 & -0.18 & -0.15 & 0.20 & 0.23 \\
$\mathrm{Ni}$ & -0.29 & 0.16 & -0.39 & $0.95^{\mathrm{a}}$ & $\mathrm{x}$ & -0.22 & 0.29 & -0.15 & -0.04 & -0.12 \\
$\mathrm{Fe}$ & 0.27 & 0.21 & $-0.94^{\mathrm{a}}$ & 0.70 & 0.52 & $\mathrm{x}$ & $-0.46^{\mathrm{a}}$ & -0.14 & -0.02 & 0.02 \\
$\mathrm{Sr}$ & 0.03 & -0.52 & $0.89^{\mathrm{a}}$ & -0.46 & -0.21 & $-0.83^{\mathrm{a}}$ & $\mathrm{x}$ & 0.11 & 0.30 & $-0.43^{\mathrm{a}}$ \\
$\mathrm{Ba}$ & 0.33 & $-0.88^{\mathrm{a}}$ & 0.26 & -0.49 & -0.39 & -0.20 & 0.26 & $\mathrm{x}$ & 0.04 & -0.07 \\
$\mathrm{~Pb}$ & -0.35 & -0.48 & $0.88^{\mathrm{a}}$ & -0.28 & -0.10 & -0.70 & 0.76 & 0.39 & $\mathrm{x}$ & 0.04 \\
$\mathrm{Age}$ & -0.33 & 0.21 & -0.09 & 0.75 & $0.88^{\mathrm{a}}$ & 0.14 & 0.14 & -0.54 & 0.03 & $\mathrm{x}$ \\
& Villages & & & & & & & & & \\
\hline
\end{tabular}

${ }^{\text {a }}$ Statistically significant correlation 

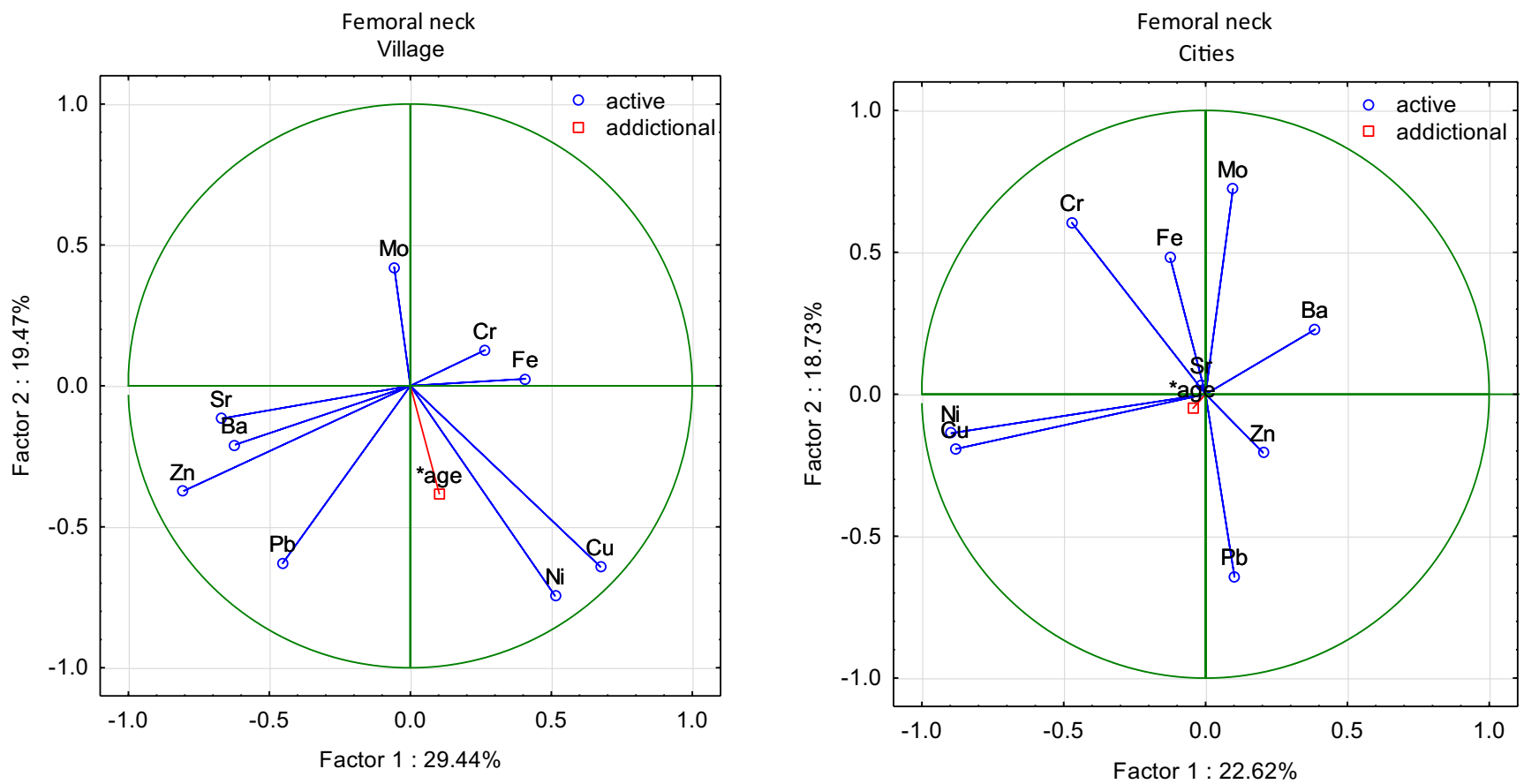

Fig. 1 A graphic illustration of Principal Components Analysis of contents of elements in femoral neck. Projection of the variables on the factor plane of the first two principal components for place of residence

\section{Molybdenum and endocrine disease}

It has been shown that in older women, Mo is released from the bones along with the increasing demineralization of bones with age. A potential Mo mechanism of action is the effect on the hormonal system by disruption of sex hormones and, indirectly, on bone health (Lewis et al. 2016). A connection with men's endocrine system has also been found, showing interactions between $\mathrm{Mo}$ and low $\mathrm{Cu}$ or $\mathrm{Zn}$ and an inverse association between Mo and semen quality (Meeker et al. 2008). Potential deficiency of $\mathrm{Zn}$ and Mo can lead to esophageal cancer in some populations (Ray et al. 2012). In our
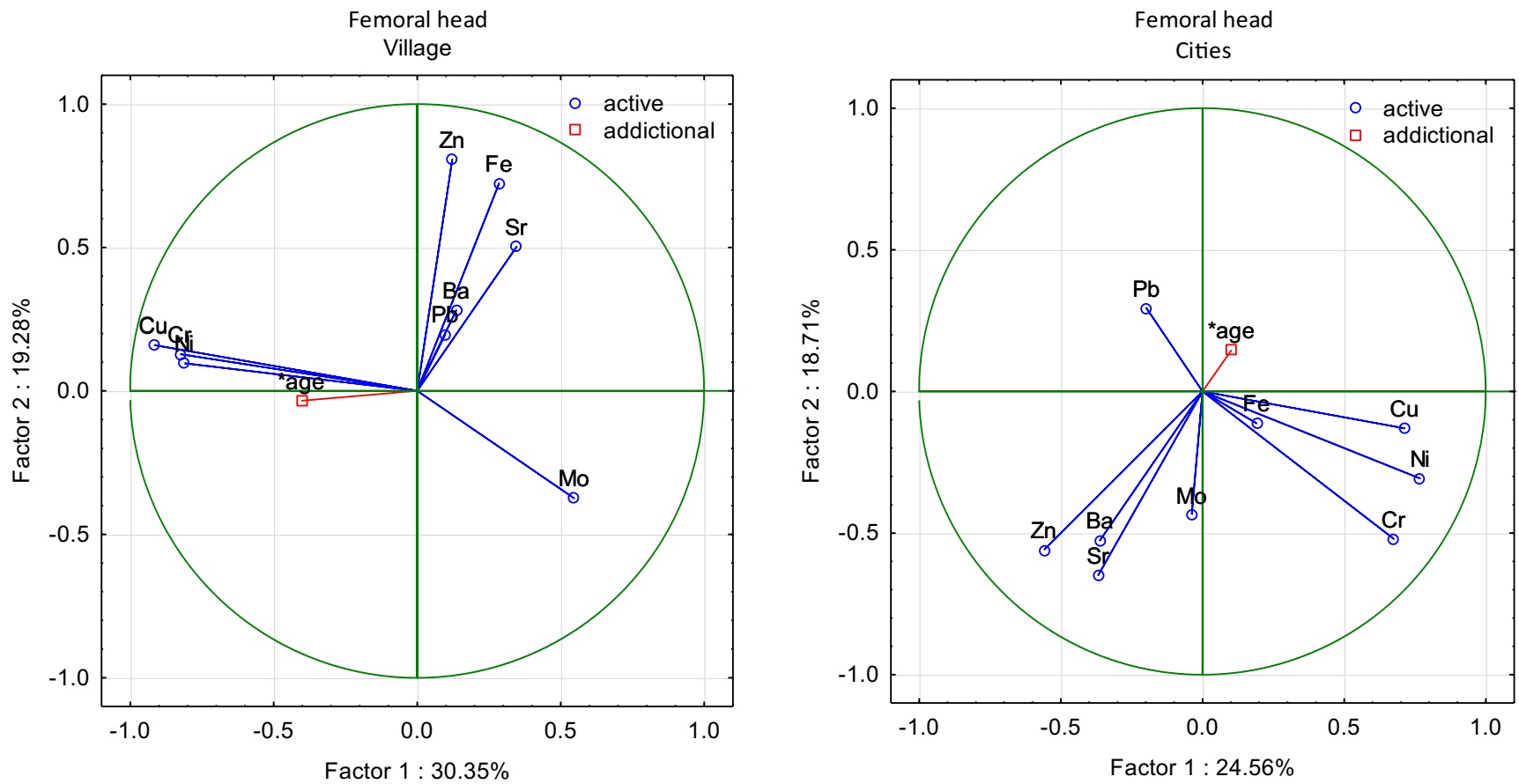

Fig. 2 A graphic illustration of Principal Components Analysis of contents of elements in femoral head. Projection of the variables on the factor plane of the first two principal components for place of residence 

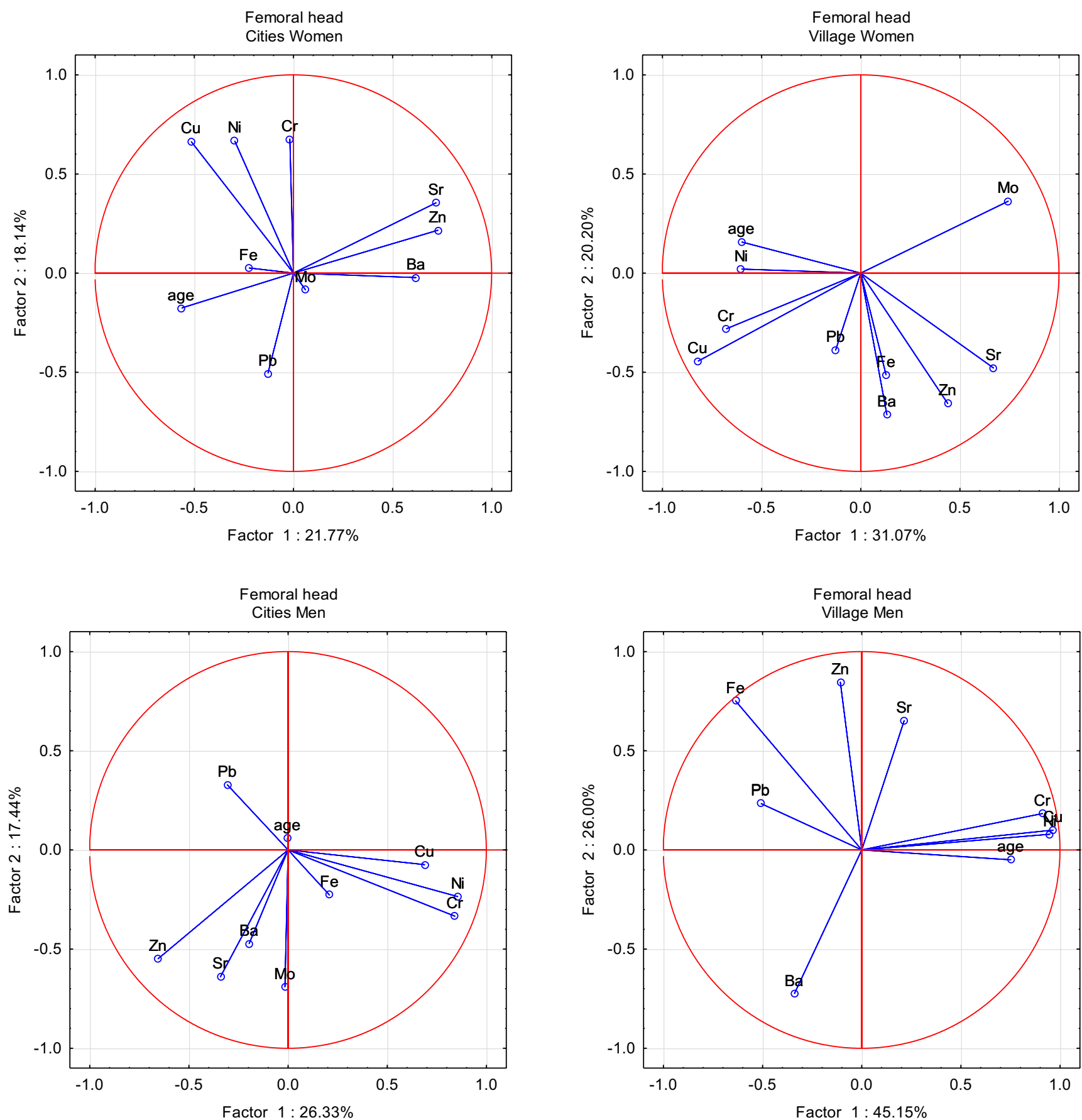

Fig. 3 A graphic illustration of Principal Components Analysis of contents of elements in femoral head of women and men. Projection of the variables on the factor plane of the first two principal components for place of residence

study, we observed several correlations between Mo and other metals, both positive and negative, which can confirm the role of this element in endocrine disease.

\section{Oxidative stress process and $\mathrm{Fe}$ and $\mathrm{Cu}$ supplementation}

In Upper Silesia, a significant correlation of 0.83 in cancellous bone and 0.51 in cortical bone (Brodziak-Dopierala et al.
2009) was found. However, Jurkiewicz et al. provide completely opposite data from Silesia $(-0.57)$ (Jurkiewicz et al. 2004). Our data oscillate between -0.03 and -0.12 in the urban population and -0.36 in the rural population in the FN similarly with date from knee joint (Roczniak et al. 2017). There was a negative correlation of $\mathrm{Zn} / \mathrm{Cu}$ in the blood of patients with diabetes and rheumatoid arthritis (Badran et al. 2016; Ullah et al. 2017). An imbalance of $\mathrm{Zn} / \mathrm{Cu}$ content is linked with diabetes and diabetic complications (Hamasaki 

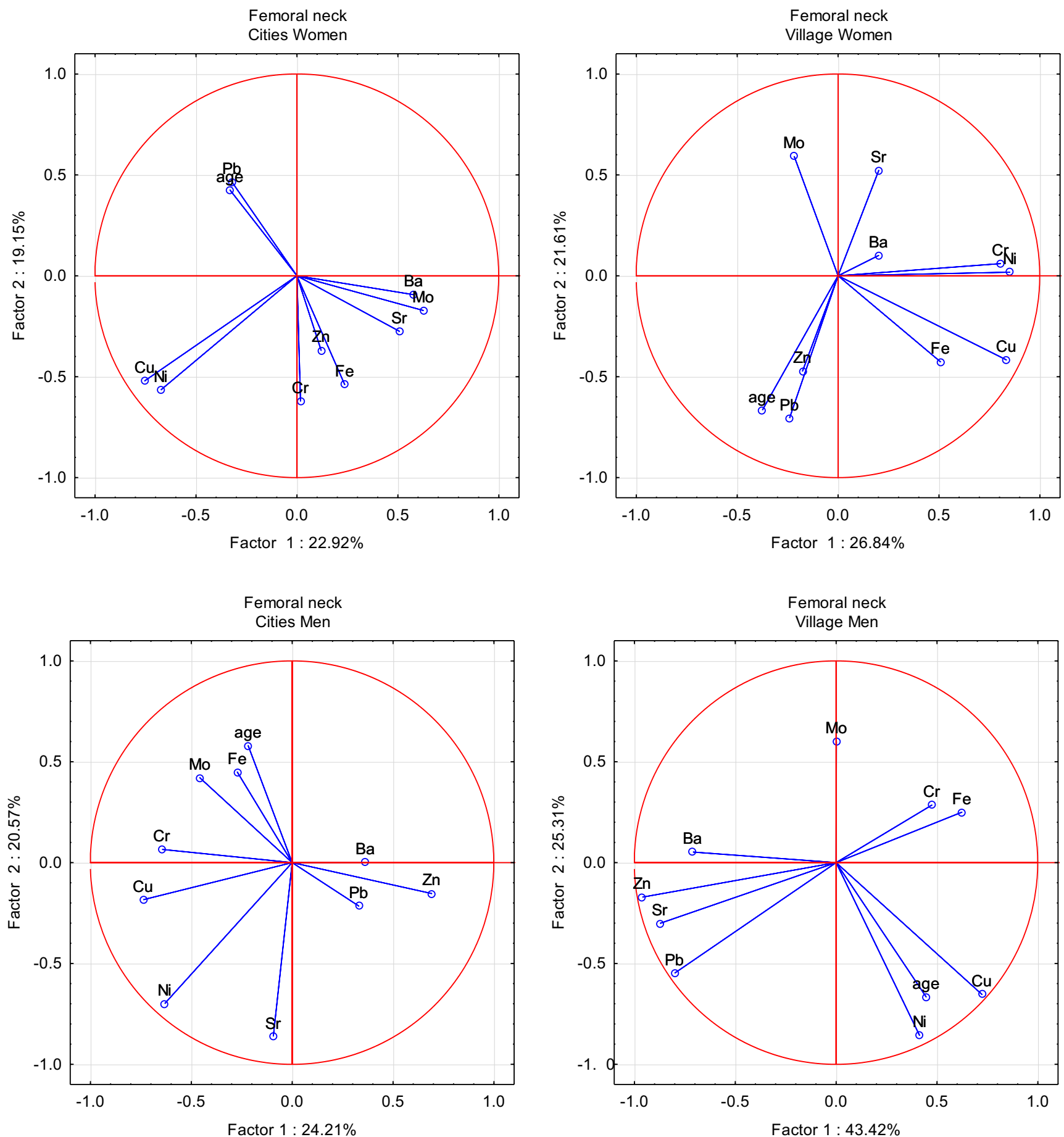

Fig. 4 A graphic illustration of Principal Components Analysis of contents of elements in femoral neck of women and men. Projection of the variables on the factor plane of the first two principal components for place of residence

et al. 2016). The study showed a higher $\mathrm{Zn} / \mathrm{Cu}$ ratio in serum in patients with knee osteoarthritis in comparison to controls (Yazar et al. 2005). Level of $\mathrm{Cu}$ in patients with osteoarthritis can be a marker of inflammation and oxidative stress. Similar correlations of elements involved in oxidative processes in cardiovascular metabolic diseases and osteoarthritis can be explained by the oxidative stress in both diseases.
Additionally, urban road dust was significantly enriched with $\mathrm{Cr}, \mathrm{Zn}$, and $\mathrm{Fe}$ compared to rural road dust (Apeagyei et al. 2011). Obesity among women is more common in rural areas than in cities (Stepaniak et al. 2016). In this study, there was no difference in the correlation of Fe with other metals like $\mathrm{Zn}$, $\mathrm{Cu}, \mathrm{Cr}$, and $\mathrm{Mo}$, depending on BMI as a factor. Correlation between the serum $\mathrm{Cu}$ concentration and age was not found 
(Strecker et al. 2013). According to the age factor, in the bones, correlation between $\mathrm{Cu}$ content and the age is not demonstrated, although higher correlation coefficients of $\mathrm{Cu} / \mathrm{age}$ can be seen in villagers.

Polish study showed a $\mathrm{Zn} / \mathrm{Fe}$ correlation in the $\mathrm{FH}$ from patients living in city, for example -0.58 in Cracow and 0.06 in Silesia (Jurkiewicz et al. 2004) and 0.3 in Upper Silesia (Brodziak-Dopierala et al. 2009). In urban populations, hair samples demonstrated a small negative correlation $(-0.05)$ (Chojnacka et al. 2005). In our study, Fe/Zn correlation in the FH was 0.41 in rural areas and 0.01 in urban areas; in the FN (a long-time marker turnover trace elements), correlation was negative for villagers $(-0.36)$ and city-dwellers $(-0.11)$. This may indicate disturbances in the course of these elements, regardless of the place of residence. In addition, studies on herbs demonstrated a higher Fe content in the rural population. $\mathrm{Zn}$ and vitamin A interact in regulating absorption of $\mathrm{Fe}$ (Graham et al. 2012). The population of pregnant women in urban areas less frequently exceeded consumption norms for vitamin A than in rural areas $(p<0.05)$ (Bojar et al. 2012). It is traced to a deficiency of $\mathrm{Zn}$ in the diet, which can lead to Fe deficiency (Graham et al. 2012).

An Australian study showed a positive correlation of $\mathrm{Fe} / \mathrm{Zn}$ in premenopausal women (Lim et al. 2015). The explanation of this interaction may be zinc supplementation provided to upregulate hepcidin leading to decreased $\mathrm{Fe}$ absorption, while increased $\mathrm{Fe}$ uptake influences the level of $\mathrm{Zn}$ transporters and disturbs $\mathrm{Zn}$ action. Studies indicate that $\mathrm{Zn} / \mathrm{Fe}$ interaction is dependent on the level of metals and their ratios (Bjørklund et al. 2017).

Only one study showed $\mathrm{Fe} / \mathrm{Cu}$ correlation in the $\mathrm{FH}$ between 0.27 and 0.36 in industrialized Polish cities (Lodz, Cracow, Silesia). In this study, a higher significant correlation was related to the FN in villagers (0.54). Suliburska et al. reported lower consumption of $\mathrm{Cu}$ in the diet of villagers (Suliburska et al. 2012). The assessment showed that the $\mathrm{Cu} / \mathrm{Fe}$ ratio was similar in the maternal vein with obesity and in controls, while significant differences were found in the $\mathrm{Zn} / \mathrm{Cu}$ ratio, which was associated with oxidative stress (Al-Saleh et al. 2006).

Brodziak et al. showed no $\mathrm{Fe} / \mathrm{Cr}$ correlation in industrial inhabitants of the Upper Silesia region (Brodziak-Dopierala et al. 2009). In our study, we found a positive correlation between the place of residence and type of bone. There is no evidence of $\mathrm{Cr}$ deficiencies in humans. Cr may disturb $\mathrm{Fe}$ absorption, decreasing the $\mathrm{Fe}$ reserve and linking to diabetes and heart disease (Prescha et al. 2014). However, supplementation of $\mathrm{Cr}$ did not influence the Fe level, independent of gender (Bjørklund et al. 2017). Those elements connect with oxidative stress but also sex, age, diet, physical condition, and pathological situation.

\section{Nickel and oxidative balance}

The contents of $\mathrm{Cr}$ and $\mathrm{Ni}$ in the femoral bone determine gender, smoking, and air pollution in the patient's place of residence (Brodziak-Dopierala et al. 2011). Inhabitants of the Upper Silesian industrial area had much higher correlation of $\mathrm{Ni} / \mathrm{Cr}$ compared to our results (Brodziak-Dopierala et al. 2009; Brodziak-Dopierala et al. 2011), which can be associated with smoking. In Poland, significantly more smokers are found among the residents of villages (Poltyn-Zaradna et al. 2016). Recent studies confirm the antioxidant properties of low concentration of $\mathrm{Cr}$ by activating enzymes that reduce Ni toxicity (Terpilowska and Siwicki 2018). A study of the endometrium in smoking women showed increases of endometrial content of $\mathrm{Cd}$ and $\mathrm{Pb}$ but not $\mathrm{Ni}$ (Rzymski et al. 2014). In this study, the correlation was lower and fluctuated between 0.11 and 0.38 . The results are lower probably because the average number of cigarettes smoked was the lowest in western Poland (Lipowicz 2015). Additional Cr, Ni, and Pb contents in rook eggshells were higher in urban areas than in rural areas, suggesting pollution with these elements in cities (Orłowski et al. 2014). Similarly, the correlation was related to $\mathrm{Ni} / \mathrm{Cu}$ as found by studies of Brodziak et al. $(0.79-0.87)$ (Brodziak-Dopierala et al. 2009; Brodziak-Dopierala et al. 2011). In this study, the correlation was lower and fluctuated between 0.45 and 0.48 in urban residents and between 0.36 and 0.86 in rural residents, which may indicate a slight difference between the village and the city in pollution in the area of the study (Great Poland Voivodeship).

Another aspect of $\mathrm{Ni}$ and $\mathrm{Fe}$ may contribute to lipid peroxidation and oxidative stress (Terpilowska and Siwicki 2018). $\mathrm{Ni}$ is probably absorbed through transport with interaction of Fe found in the hemoglobin and participates in oxygen transport (Zambelli et al. 2016). In our study, Fe/Ni correlation was significantly positive in the FN of men and women from rural areas. This may be due to the fact that in Poland, people living in cities have more risk factors for atherosclerosis than those living in rural areas (Mierzecki et al. 2014).

According to Ni and Zn, interaction may stabilize the RNA structure, DNA, and ribosomal conformation and is an enzyme activator. Antagonistic actions Ni/Zn may result: $\mathrm{Zn}$ may cause $\mathrm{Ni}$-induced toxicity in the liver. $\mathrm{Ni}-\mathrm{Zn}$ supplementation led to decreased osteons (Martiniaková et al. 2009). Our study showed negative $\mathrm{Ni} / \mathrm{Zn}$ correlation mainly in men, and the values were higher in rural areas, with the exception of the $\mathrm{FH}$ of men from villages. Low variation in exposure to nickel pollution between cities and villages in Wielkopolska may indicate higher nickel exposure in rural areas. This hypothesis can confirm the results of $\mathrm{Ni}$ accumulation with age only in men from rural areas.

\section{Barium competes with calcium}

$\mathrm{Ba}$ has a larger ionic radius than $\mathrm{Ca}$ and $\mathrm{Sr}$, and incorporation of $\mathrm{Ba}$ may have similar effects as $\mathrm{Sr}$ on the formation of smaller and stronger bone minerals. Lower content of $\mathrm{Ba}$ had an influence on osteoporotic fractures, but this effect did 
not show in deficiency of Sr or Zn. Aaseth et al. suggested that low $\mathrm{Ba}$ content may increase risk fracture, and Ba supplements may potentially have an effect on the treatment of osteoporosis (Aaseth et al. 2012). Some studies have shown lower BMD in rural women than urban women, although other data indicate no statistically significant differences in BMD between urban and rural populations (Filip and Zagórski 2001). Our study showed a positive $\mathrm{Sr} / \mathrm{Ba}$ correlation regardless of place of residence. Ba may have a beneficial effect on bone strength like $\mathrm{Sr}$. Ba competes with $\mathrm{Ca}$, replacing it in chemical and physiological processes, particularly regarding the action of adrenal neurotransmitters (Kravchenko et al. 2014). The Ba content in the air is higher in cities, and its source is industrial pollution. The content of $\mathrm{Ba}$ in the bone decreases with age, as we confirmed in this study, and it is associated with the loss of bone mass in which the element accumulates. However, this decrease is lower in cities (minimum -0.15$)$ compared to rural areas $(-0.54)$. The greatest number of significant correlation coefficients was observed in rural areas. Synergic reactions of pharyngeal tonsils for boys from rural regions concerned $\mathrm{Ba} / \mathrm{Cr}(0.91)$ (Nogaj et al. 2011). The most probable cause is exposure to $\mathrm{Ba}$ by pollution of the urban environment. In the case of facial bone, the level of $\mathrm{Ba}$ increased with the age of the subjects. Ba increased with age in bone and teeth (Fischer et al. 2014). In our study, Ba content decreased with age most statistically significantly in the $\mathrm{FH}$ of rural residents.

\section{Strontium}

Budis et al. showed a positive $\mathrm{Fe} / \mathrm{Sr}$ correlation in the compact and cancellous bone in a predominantly urban population (Budis et al. 2014). In this study, $\mathrm{Fe} / \mathrm{Sr}$ was significantly negative in the FN of men in urban and rural areas. In women, no significant correlation was observed between $\mathrm{Sr}$ or $\mathrm{Fe}$ in blood and BMD (Unfer et al. 2007). In men (prostatic gland), a statistically significant negative $\mathrm{Zn} / \mathrm{Sr}$ correlation and positive $\mathrm{Fe} / \mathrm{Sr}$ correlation were found (Zaichick and Zaichick 2014). Positive $\mathrm{Sr} / \mathrm{Zn}$ correlation independent of place of residence agrees with our results (Zaichick et al. 2011). Moreover, previous research showed that $\mathrm{Sr}$ and $\mathrm{Zn}$ concentrations in bone decrease with age (Wang et al. 2008). In this study, these correlations were found only in the FN of the urban population, which may be related to the loss of bone mass with age.

\section{Lead}

A previous study showed that $\mathrm{Pb}$ increases with age, especially in the case of higher $\mathrm{Pb}$ exposure in the past (Bjermo et al. 2013). Our study showed that $\mathrm{Pb}$ increases in the $\mathrm{FN}$ with age only in villagers. This is probably related to a lower incidence of osteoporosis in the rural population.

\section{Conclusions}

We showed significant dissimilarity between people living in cities and in villages in terms of the five elements: $\mathrm{Ni}, \mathrm{Mo}, \mathrm{Cr}$, $\mathrm{Cu}$, and $\mathrm{Zn}$. Ni and $\mathrm{Pb}$ increased and $\mathrm{Ba}$ decreased with age only in villagers. $\mathrm{Sr}$ decreased with age only in people living in cities. $\mathrm{Mo} / \mathrm{Cr}$ correlation was negative in villagers. $\mathrm{Mo} / \mathrm{Pb}$ correlation was higher in men than in women. We found highly positive $\mathrm{Cu} / \mathrm{Ni}$ correlation in the FN. Differences in correlation of metal content in femoral bone between urban and rural populations can influence environmental factors (pollution) and age. In villagers, Fe/ $\mathrm{Zn}$ correlation in the $\mathrm{FH}$ was more positive and negative in the FN; one of the reasons may be higher $\mathrm{Fe}$ content in the rural population. Trace mineral micronutrients like $\mathrm{Fe}, \mathrm{Zn}, \mathrm{Cu}, \mathrm{Mo}$, and $\mathrm{Cr}$ are essential for regulating inflammatory pathways. The contents of metals and their correlations in various tissues can therefore be treated as a marker of oxidative stress (as a long-term marker in bone), whereas there is no evidence of the effect of supplementation on oxidative stress. Positive correlation of $\mathrm{Ni} / \mathrm{Fe}$ was significant in the FN of villagers independent of sex, and $\mathrm{Ni} / \mathrm{Zn}$ correlation was found only in urban females in the $\mathrm{FH}$.

Funding This project was partly financed by the National Science Center in Poland (MINIATURA 1 2017), under grant agreement no. DEC-2017/ 01/X/NZ5/00308.

Open Access This article is distributed under the terms of the Creative Commons Attribution 4.0 International License (http:// creativecommons.org/licenses/by/4.0/), which permits unrestricted use, distribution, and reproduction in any medium, provided you give appropriate credit to the original author(s) and the source, provide a link to the Creative Commons license, and indicate if changes were made.

\section{References}

Aaseth J, Boivin G, Andersen O (2012) Osteoporosis and trace elements - an overview. J Trace Elem Med Biol 26(2-3):149-152

Ajibola, R., Ogundahunsi, O., Soyinka, O., Ogunyemi, E., \& Odewabi, A. (2014). Serum chromium, molybdenum, zinc and magnesium levels in diabetes mellitus patients in Sagamu, South West Nigeria. Asian Journal of Medical Sciences, 6(2), 15-19

Al-Saleh, E., Nandakumaran, M., Al-Harmi, J., Sadan, T., \& Al-Enezi, H. (2006). Maternal-fetal status of copper, iron, molybdenum, selenium, and zinc in obese pregnant women in late gestation. Biol Trace Elem Res, 113(2), 113-123

Apeagyei E, Bank MS, Spengler JD (2011) Distribution of heavy metals in road dust along an urban-rural gradient in Massachusetts. Atm Environ 45(13):2310-2323

Atari-Hajipirloo S, Valizadeh N, Khadem-Ansari M-H, Rasmi Y, Kheradmand F (2016) Altered concentrations of copper, zinc, and iron are associated with increased levels of glycated hemoglobin in patients with type 2 diabetes mellitus and their first-degree relatives. Int J Endocrinol Metab 14(2):e33273 
Badran M, Morsy R, Soliman H, Elnimr T (2016) Assessment of trace elements levels in patients with type 2 diabetes using multivariate statistical analysis. J Trace Elem Med Biol 33:114-119

Berglund M, Akesson A, Bjellerup P, Vahter M (2000) Metal-bone interactions. Toxicol Lett 112-113:219-225

Bjermo H, Sand S, Nälsén C, Lundh T, Barbieri HE, Pearson M et al (2013) Lead, mercury, and cadmium in blood and their relation to diet among Swedish adults. Food Chem Toxicol 57:161-169

Bjørklund G, Aaseth J, Skalny AV, Suliburska J, Skalnaya MG, Nikonorov AA, Tinkov AA (2017) Interactions of iron with manganese, zinc, chromium, and selenium as related to prophylaxis and treatment of iron deficiency. J Trace Elem Med Biol 41:41-53

Bojar I, Owoc A, Humeniuk E, Wierzba W, Fronczak A (2012) Inappropriate consumption of vitamins and minerals by pregnant women in Poland. Ann Agric Environ Med 19(2):263-266

Boonen S, Aerssens J, Dequeker J, Nicholson P, Cheng XG, Lowet G, Verbeke G, Bouillon R (1997) Age-associated decline in human femoral neck cortical and trabecular content of insulin-like growth factor I: potential implications for age-related (type II) osteoporotic fracture occurrence. Calcif Tissue Int 61(3):173-178

Brodziak-Dopierala B, Kwapulinski J, Kusz D, Gajda Z, Sobczyk K (2009) Interactions between concentrations of chemical elements in human femoral heads. Arch Environ Cont Toxicol 57(1):203-210

Brodziak-Dopierala B, Kwapulinski J, Sobczyk K, Kowol J (2011) The occurrence of nickel and other elements in tissues of the hip joint. Ecotox Environ Saf 74(4):630-635

Budis H, Kalisinska E, Lanocha N, Kosik-Bogacka D, Sokolowski S, Dobiecki K, Kolodziej Ł, Bohatyrewicz A (2014) The concentration of manganese, iron, and strontium in hip joint bone obtained from patients undergoing hip replacement surgery. J Trace Elem Med Biol 28(1):39-44

Chojnacka K, Gorecka H, Chojnacki A, Gorecki H (2005) Inter-element interactions in human hair. Environ Toxicol Pharma 20(2):368-374

Feng W, Cui X, Liu B, Liu C, Xiao Y, Lu W, Guo H, He M, Zhang X, Yuan J, Chen W, Wu T (2015) Association of urinary metal profiles with altered glucose levels and diabetes risk: a population-based study in China. PloS One 10(4):e0123742

Filip RS, Zagórski J (2001) Bone mineral density and osteoporosis in rural and urban women. Epidemiological study of the Lublin region (Eastern Poland). Ann Agric Environ Med 8:221-226

Fischer A, Malara P, Wiechuła D (2014) The study of barium concentration in deciduous teeth, impacted teeth, and facial bones of Polish residents. Biol Trace Elem Res 161(1):32-37

Flores CR, Puga MP, Wrobel K, Sevilla MEG, Wrobel K (2011) Trace elements status in diabetes mellitus type 2: possible role of the interaction between molybdenum and copper in the progress of typical complications. Diabetes Res Clin Pr 91(3):333-341

Fougère B, Vellas B, Billet S, Martin PJ, Gallucci M, Cesari M (2015) Air pollution modifies the association between successful and pathological aging throughout the frailty condition. Ageing Res Rev 24:299-303

Frankowski M, Zioła-Frankowska A, Siepak J (2013) From soil to leaves - aluminum fractionation by single step extraction procedures in polluted and protected areas. J Environ Manag 127:1-9

Freitas EPS, Cunha ATO, Aquino SLS, Pedrosa LFC, Sena-Evangelista KCM (2017) Zinc status biomarkers and cardiometabolic risk factors in metabolic syndrome: a case control study. Nutrients 9(2):175 1-13

Gonzalez-Reimers E, Martín-González C, Galindo-Martin L, AlemanValls MR, Velasco-Vázquez J, Arnay-de-la-rosa M, PérezHernández O, Luis RH (2014) Lead, cadmium and zinc in hair samples: relationship with dietary habits and urban environment. Biol Trace Elem Res 157(3):205-210

Graham RD, Knez M, Welch RM (2012) How much nutritional iron deficiency in humans globally is due to an underlying zinc deficiency? Adv Agro 115:1-40
Güner S, Tay A, Altan V, Özçelikay A (2001) Effect of sodium molybdate on fructose-induced hyperinsulinemia and hypertension in rats. Trace Elem Electroly 18(1):39-46

Hamasaki H, Kawashima Y, Yanai H (2016) Serum $\mathrm{Zn} / \mathrm{Cu}$ ratio is associated with renal function, glycemic control, and metabolic parameters in Japanese patients with and without type 2 diabetes: a crosssectional study. Front Endocrin 7:147 1-8

Jurkiewicz A, Wiechula D, Nowak R, Gazdzik T, Loska K (2004) Metal content in femoral head spongious bone of people living in regions of different degrees of environmental pollution in Southern and Middle Poland. Ecotox Environ Saf 59(1):95-101

Kabir E, Ray S, Kim KH, Yoon H, Jeon E, Kim YS, Cho YS, Yun ST, Brown RJC (2012) Current status of trace metal pollution in soils affected by industrial activities. Sci World J 2012:916705 1-18

Kazi TG, Afridi HI, Kazi N, Jamali MK, Arain MB, Jalbani N, Kandhro GA (2008) Copper, chromium, manganese, iron, nickel, and zinc levels in biological samples of diabetes mellitus patients. Biol Trace Elem Res 122(1):1-18

Kravchenko J, Darrah TH, Miller RK, Lyerly HK, Vengosh A (2014) A review of the health impacts of barium from natural and anthropogenic exposure. Environ Geochem Health 36(4):797-814

Lanocha-Arendarczyk N, Kosik-Bogacka ID, Prokopowicz A, Kalisinska E, Sokolowski S, Karaczun M, Zietek P, Podlasińska J, Pilarczyk B, Tomza-Marciniak A, Baranowska-Bosiacka I, Gutowska I, Safranow K, Chlubek D (2015) The effect of risk factors on the levels of chemical elements in the tibial plateau of patients with osteoarthritis following knee surgery. BioMed Res Int: 65028210 pages

Lazarus M, Orct T, Reljić S, Sedak M, Bilandžić N, Jurasović J, Huber D (2018) Trace and macro elements in the femoral bone as indicators of long-term environmental exposure to toxic metals in European brown bear (Ursus arctos) from Croatia. Environ Sci Pollut R 25(22):21656-21670

Lewis RC, Johns LE, Meeker JD (2016) Exploratory analysis of the potential relationship between urinary molybdenum and bone mineral density among adult men and women from NHANES 2007 2010. Chemosph 164:677-682

Lim K, Booth A, Szymlek-Gay EA, Gibson RS, Bailey KB, Irving D, Nowson C, Riddel L (2015) Associations between dietary iron and zinc intakes, and between biochemical iron and zinc status in women. Nutr 7(4):2983-2999

Lipowicz A (2015) Disparities in health status between rural and urban adult males in Lower Silesia, Poland. Anthropol Anz 72(1):13-25

Maanvizhi S, Boppana T, Krishnan C, Arumugam G (2014) Metal complexes in the management of diabetes mellitus: a new therapeutic strategy. Int J Pharm Sci 6(7):40-44

Martiniaková M, Omelka R, Grosskopf B, Chovancová H, Massányi P, Chrenek P (2009) Effects of dietary supplementation of nickel and nickel-zinc on femoral bone structure in rabbits. Acta Veterin Scandin 51:52 1-6

Matés JM, Segura JA, Alonso FJ, Márquez J (2008) Intracellular redox status and oxidative stress: implications for cell proliferation, apoptosis, and carcinogenesis. Arch Toxicol 82:273-299

Meeker JD, Rossano MG, Protas B, Diamond MP, Puscheck E, Daly D, Paneth N, Wirth JJ (2008) Cadmium, lead, and other metals in relation to semen quality: human evidence for molybdenum as a male reproductive toxicant. Environ Health Persp 116(11):1473-1479

Mierzecki A, Kloda K, Gryko A, Czarnowski D, Chelstowski K (2014) Atherosclerosis risk factors in rural and urban adult populations living in Poland. Exp Clin Cardiol 20(8):3152-3157

Nogaj E, Kwapuliński J, Misiołek H, Lisowska G, Rostkowska-Nadolska B, Bień S, Nogaj P (2011) Pharyngeal tonsil as new biomarker of pollution on example of barium. Pol J Environ Stud 20(1):167-172

Orłowski G, Kasprzykowski Z, Dobicki W, Pokorny P, Wuczyński A, Polechoński R, Mazgajski TD (2014) Residues of chromium, 
nickel, cadmium and lead in rook Corvus frugilegus eggshells from urban and rural areas of Poland. Sci Tot Environ 490:1057-1064

Połtyn-Zaradna K, Basiak A, Zatońska K, Wołyniec M, Dąbrowska DG, Szuba A, Zatoński WA (2016) Prevalence of tobacco smoking among participants of PURE Poland study. J Health Inequal 2(2): 142-147

Prescha A, Krzysik M, Zabłocka-Słowińska K, Grajeta H (2014) Effects of exposure to dietary chromium on tissue mineral contents in rats fed diets with fiber. Biol Trace Elem Res 159(1-3):325-331

Ray S, Das D, Ghosh T, Ghosh A (2012) The levels of zinc and molybdenum in hair and food grain in areas of high and low incidence of esophageal cancer: a comparative study. Glob J Health Sci 4(4): $168-175$

Roczniak W, Brodziak-Dopierała B, Cipora E, Jakóbik-Kolon A, Kluczka J, Babuśka-Roczniak M (2017) Factors that affect the content of cadmium, nickel, copper and zinc in tissues of the knee joint. Biol Trace Elem Res 178(2):201-209

Rzymski P, Rzymski P, Tomczyk K, Niedzielski P, Jakubowski K, Poniedziałek B, Opala T (2014) Metal status in human endometrium: relation to cigarette smoking and histological lesions. Environ Res 132:328-333

Stepaniak U, Micek A, Waśkiewicz A, Bielecki W, Drygas W, Janion M, Kozakiewicz K, Niklas A, Puch-Walczak A, Pajak A (2016) Prevalence of general and abdominal obesity and overweight among adults in Poland results of the WOBASZ II study (2013-2014) and comparison with the WOBASZ study (2003-2005). Pol Arch Med Wewn 126(9):662-671

Strecker D, Mierzecki A, Radomska K (2013) Copper levels in patients with rheumatoid arthritis. Ann Agric Environ Med 20(2):312-316

Suliburska J, Bogdanski P, Duda G, Pupek-Musialik D, Piatek J, Zukiewicz-Sobczak W (2012) An assessment of dietary intake and state of nutritional in hypertensive patients from rural and urban areas of Greater Poland. Ann Agric Environ Med 19(3):339-343

Terpilowska S, Siwicki AK (2018) Interactions between chromium (III) and iron (III), molybdenum (III) or nickel (II): cytotoxicity, genotoxicity and mutagenicity studies. Chemosphere 201:780-789

Ullah Z, Ullah MI, Hussain S, Kaul H, Lone KP (2017) Determination of serum trace elements $(\mathrm{Zn}, \mathrm{Cu}$, and $\mathrm{Fe})$ in Pakistani patients with rheumatoid arthritis. Biol Trace Elem Res 175(1):10-16

Unfer TC, Müller EI, de Moraes Flores ÉM, Dressler VL, da Silva JC, Duarte MM, Emanuelli T (2007) Sr and Fe relationship with hormone replacement therapy and bone mineral density. Clin Chim Ac 384(1-2):113-117
Valko M, Leibfritz D, Moncol J, Cronin MTD, Mazur M, Telser J (2007) Free radicals and antioxidants in normal physiological functions and human disease. Int J Biochem Cell Biol 39:44-84

Van Ryssen J (1994) The effectiveness of using supplementary zinc and molybdenum to reduce the copper content in the liver of hypercuprotic sheep. J South Afric Veter Assoc 65(2):59-63

Wang C, Eisa MH, Jin W, Shen H, Mi Y, Gao J, Zhou Y, Yao H, Zhao Y (2008) Age-related elemental change in bones. Nucl Instrum Methods Phys Res B 266(8):1619-1622

Wang X, Chen B, Sun J, Jiang Y, Zhang H, Zhang P, Fei B, Xu Y (2018) Iron-induced oxidative stress stimulates osteoclast differentiation via NF- $\mathrm{KB}$ signaling pathway in mouse model. Metab Clin Exp 83: $167-176$

Yazar M, Sarban S, Kocyigit A, Isikan UE (2005) Synovial fluid and plasma selenium, copper, zinc, and iron concentrations in patients with rheumatoid arthritis and osteoarthritis. Biol Trace Elem Res 106(2):123-132

Zaichick V, Zaichick S (2014) Relations of bromine, iron, rubidium, strontium, and zinc content to morphometric parameters in pediatric and nonhyperplastic young adult prostate glands. Biol Trace Elem Res 157(3):195-204

Zaichick S, Zaichick V, Karandashev VK, Moskvina IR (2011) The effect of age and gender on 59 trace-element contents in human rib bone investigated by inductively coupled plasma mass spectrometry. Biol Trace Elem Res 143(1):41-57

Zambelli B, Uversky VN, Ciurli S (2016) Nickel impact on human health: an intrinsic disorder perspective. Biochimica et Biophysica Acta (BBA)-Proteins and Proteomics 1864(12):1714-1731

Zatońska K, Połtyn-Zaradna K, Einhorn J, Wołyniec M, GawełDąbrowska D, Szuba A, Zatoński W (2017) Differences in prevalence of diabetes mellitus type 2 and impaired fasting glucose between urban and rural areas according to PURE Poland substudy. Int J Diabetes Dev C 37(3):305-312

Zioła-Frankowska A, Dąbrowski M, Kubaszewski Ł, Rogala P, Frankowski M (2015a) Factors affecting the aluminium content of human femoral head and neck. J Inorg Biochem 152:167-173

Zioła-Frankowska A, Kubaszewski Ł, Dąbrowski M, Kowalski A, Rogala P, Strzyżewski W, Łabędź W, Uklejewski R, Novotny K, Kanicky V, Frankowski M (2015b) The content of the 14 metals in cancellous and cortical bone of the hip joint affected by osteoarthritis. BioMed Res Int Article ID 815648:23 pages

Zioła-Frankowska A, Dąbrowski M, Kubaszewski Ł, Rogala P, Kowalski P, Frankowski M (2017) An analysis of factors affecting the mercury content in the human femoral bone. Environ Sci Pollut Res 24(1): $547-557$ 